\title{
Щодо підвищення якості економічного розвитку країни шляхом урахування кореляційних зв'язків між воєнними витратами та макроекономічними показниками країн
}

\author{
Олег Семененко ${ }^{1}$ A; Ігор Москаленко ${ }^{2}$ В; Марина Абрамова ${ }^{3}$ A; \\ Вікторія Коверга ${ }^{4}$ А; Лілія Семененко ${ }^{5}$ в ; Ігор Целіщев ${ }^{6}$ C \\ А Центральний науково-дослідний інститут Збройних Сил України, пр-кт Повітрофлотський 28, м. Київ, 03049, Україна

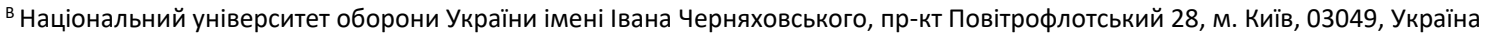 \\ с Кафедра військової підготовки Національного авіаційного університету, вул. Медова 1, м. Київ, 03048, Україна
}

Received: July 29, 2021 | Revised: August 25, 2021 | Accepted: August 31, 2021

DOI: $10.33445 /$ sds.2021.11.4.9

\begin{abstract}
Анотація
Проведений авторами аналіз наявних відкритих публікацій надав можливість визначити одним із можливих недоліків покращення економічного розвитку держави, неврахування наслідків проявів зв'язків між зміною обсягів воєнних витрат та макроекономічними показниками держави під час середньо- та довгострокового державного планування.

На думку авторів врахування закордонного досвіду $є$ доцільним для всебічного аналізу можливостей трансформації власних економічних процесів. За допомогою проведеного кореляційного аналізу отримано узагальнені результати визначення можливих зв'язків/залежностей між змінами обсягів витрат на потреби Міністерства Оборони (МО) та рівня валових внутрішніх витрат (ВВП), інфляції, найближчих до України та провідних країн Світу. Це надало можливість виокремити країни з можливим позитивним впливом оборонних витрат на їх економічні процеси. Подальші дослідження за даним напрямом можуть визначити ряд аналогій, які доцільно використовувати для удосконалення політики економічного розвитку власної держави.
\end{abstract}

Ключові слова: воєнні витрати, економічний розвиток, макроекономічні показники, кореляційний аналіз, коефіцієнт Фехнера, коефіцієнт Спірмена, коефіцієнт Кендела.

\section{Постановка проблеми}

Сучасна державна довгострокова політика потребує більш конкретизованих дій для реалізації її цілей. Так як оборонна політика $\epsilon$ однією з її елементів, тому аналіз можливого впливу воєнних витрат на зміну макроекономічних показників країни $\epsilon$ одним з актуальних питань, що доцільно розглядати на етапі визначення необхідного обсягу асигнувань на утримання i вдосконалення Збройних Сил (3С) на майбутнє.
Такий вплив може проявлятися в двох аспектах: з одного боку, надмірні воєнні витрати можуть відволікати ресурси від вирішення актуальних соціальноекономічних завдань, підвищення добробуту населення, а $з$ іншого, “розумні" воєнні витрати, спрямовані насамперед на виробництво високотехнологічних систем озброєнь та іншої продукції воєнного i подвійного призначення, стимулюють розвиток наукоємного виробництва, створюють робочі місця і розширюють

\footnotetext{
${ }^{1}$ Corresponding author: д. військ. н., с.н.с., начальник відділу, e-mail: aosemenenko@ukr.net, ORCID: 0000-0001-6477-3414

2 здобувач наукового ступеня, e-mail: aosemenenko@ukr.net, ORCID: 0000-0002-7822-6419

${ }^{3}$ кандидат економічних наук, e-mail: aosemenenko@ukr.net, ORCID: 0000-0001-7644-9988

${ }^{4}$ здобувач наукового ступеня, e-mail: aosemenenko@ukr.net, ORCID: 0000-0002-9776-5522

5 здобувач наукового ступеня, e-mail: selin-ua@ukr.net, ORCID: 0000-0002-5628-3586

${ }^{6}$ e-mail: aosemenenko@ukr.net, ORCID: 0000-0002-8027-4110
} 
можливості експорту, що здійснює позитивний вплив на економіку і знаходить своє відображення в зміні обсягів внутрішнього валового продукту (ВВП), зайнятості, рівня інфляції, реальних доходів населення, структури промислового виробництва тощо [1;2].

Відсутність механізму аналізу можливих впливів оборонних витрат на макроекономічні показники породжує не тільки невизначеність у коротко-, середньота довгостроковому виконанні цілей державного планування, а й може слугувати полем для виникнення ризиків та загроз невиконанню поставлених цілей оборонного спектру на середньо- та довгострокову перспективу.

\section{Аналіз останніх досліджень та публікацій}

Розвиток економіки кожної країни має суто індивідуальний характер та залежить від багатьох чинників. Відомі публікації, присвячені систематизації впливу величини воєнних витрат на економіку країни, причому найчастіше це робиться із застосуванням складних математичних і статистичних моделей [3; 4; 17-19]. Їх автори не приходять, однак, до єдиної думки щодо загального напрямку впливу таких витрат на економічне зростання. Багато дослідників розглядають воєнні витрати як альтернативу інвестиціям у невійськові галузі [5-7] i, порівнюючи ефективності, показують, що вони негативно впливають на інвестиції і, отже, на економічне зростання. $€$ й такі, які вказують на існування прямої залежності між воєнними витратами і виробництвом, особливо металургією та іншими технологічними галузями [8; 9]. Практично всі автори, які досліджували дане питання сходяться на тому, що існують фактори, що впливають на економічний розвиток як позитивно, так і негативно. Тобто $\epsilon$ якийсь оптимум у величині воєнних витрат [1013]. Слід зазначити, що існують прямі і непрямі форми взаємного впливу воєнних витрат i показників економічного зростання. До перших належить насамперед статистична методологія розрахунку показника валового внутрішнього продукту (ВВП), яка ставить цей показник в безпосередню залежність від воєнних витрат [15; 16; 20-22]. Стосовно оборонної галузі це означає, що вартість послуг оборони (що включається до ВВП) розраховується як сума витрат на озброєння, утримання особового складу, амортизацію основного капіталу і поточних матеріальних витрат. Іншими словами, згідно з міжнародною практикою всі кошти, витрачені на закупівлю озброєння, розглядаються як витрати на кінцеве споживання суспільства в цілому і включаються до ВВП. Таким чином, математично наявна пряма залежність між темпами економічного зростання, основним показником якого $€$ ВВП, $\mathrm{i}$ витратами на оборону, включаючи закупівлі продукції воєнного призначення (більші витрати на оборону автоматично означають більший ВВП). Однак, на практиці має місце більш складна залежність. Так, витрати на оборону статистично включаються до ВВП і тим самим збільшують його розмір. Однак необхідно враховувати, що ті ж самі кошти могли б бути використані суспільством на інші цілі і, можливо, більш ефективно з економічної точки зору. Наприклад, вони могли б бути інвестовані у виробництво будь-яких товарів і послуг з високою доданою вартістю. 3 цієї точки зору можна говорити про певну "упущеної вигоди".

\section{Постановка завдання}

Метою статті $\epsilon$ виокремлення країн 3 найстійкішим кореляційним зв'язком між зміною оборонних витрат та деякими їх макроекономічними показниками, що $\epsilon$ необхідним для проведення подальших досліджень за тематикою узагальнення зарубіжного досвіду підвищення якості економічного розвитку за рахунок управління воєнними витратами. 


\section{Виклад основного матеріалу}

Зазвичай досліджується співвідношення між воєнними витратами та економічним зростанням, а не розвитком, хоча перше $\epsilon$ лише необхідна умова для другого. Крім того, воєнні витрати представляють лише один 3 аспектів мілітаризації суспільства і $\epsilon$ показником витрат, а не результатів. Для аналізу будь-яких емпіричних даних та їх практичного застосування при державному регулюванні потрібна теорія. Однак дослідження економічного ефекту воєнних витрат ускладнюється тим, що вони, як правило, не розглядаються як особливий вид господарської діяльності. Необхідно зауважити, що існують такі основні теоретичні підходи: неокласичний, кейнсіанський, інституційний, марксистський [11].

Представники неокласичного підходу розглядають воєнні витрати як важливий фактор, що впливає на виробництво і має реальний динамічний ефект. Кейнсіанці вважають, що держава повинна активно використовувати воєнні витрати як інструмент господарського регулювання, що сприяє зростанню виробництва за рахунок ефекту мультиплікації в умовах неефективного сукупного попиту. Вони виходять з того, що нарощування воєнних витрат може призвести до більш повного використання виробничих потужностей, збільшення прибутків і, отже, до зростання інвестицій і економічного зростання. В рамках інституціонального напрямку, який $\epsilon$ радикально ліберальним, як правило, робиться наголос на такі наслідки воєнних витрат, як зміна народногосподарської ефективності і формування впливових зацікавлених груп. Представники марксистського підходу вважають, що воєнні витрати відіграють важливу, але суперечливу роль.

Важливою умовою успіху досліджень $\epsilon$ врахування специфіки країн, що розвиваються. У багатьох з них воєнні витрати в той чи інший період в основному не залежать від економічного становища і підкоряються швидше внутрішній політиці держави. Загальна економічна ситуація визначає параметри воєнних витрат на тривалому відрізку часу. При цьому необхідно також враховувати стратегічні фактори, безпека і суб'єктивне сприйняття загрози (як зовнішньої, так і внутрішньої).

В якості показника, що відображає фактор доходів, часто використовують ВВП на душу населення. Його більш високе значення зазвичай відповідає високому рівню воєнних витрат, що, правда, не завжди відбивається в збільшенні їх частки у ВВП. Важливим показником $€$ структура державних витрат по відношенню до ВВП.

У літературі, присвяченій емпіричним дослідженням, розглядається вплив воєнних витрат на економічне зростання за такими основними каналами [14]: праця, капітал, зовнішні відносини, попит, соціополітичні чинники.

Ще раз зазначимо, що воєнні витрати здатні створювати умови для розвитку. Збройні сили можуть надавати забезпечувати контроль, дисципліну праці і стримуючи внутрішні конфлікти, готуючи кваліфіковані кадри для цивільного сектора. Однак технологія військового сектора - капіталомістка і настільки далека від решти економіки, що ії побічні ефекти (“спін-офф") вважають незначними. Він, як правило, відтягує кваліфікованих працівників з цивільного сектора. До того ж військові режими в більшості випадків $\epsilon$ консервативними, корумпованими неефективними.

Зустрічаються різні, нерідко суперечливі погляди щодо взаємозв'язку воєнної економіки та економічного зростання. Для найбільш великих держав спостерігався як інтенсивний економічний ріст при високих воєнних витратах, так і не менш інтенсивний ріст при низьких.

Слід зазначити, що існує взаємний вплив воєнних витрат і показників економічного зростання. ВВП $€$ показником економічного зростання. Існують наступні складові ВВП пов'язані, наприклад, 3 воєнним виробництвом: виробництво продукції 
подвійного призначення, яка може використовуватися як для воєнних, так і для цивільних потреб; виробництво оборонними підприємствами тільки цивільної продукції; експорт озброєнь і військової техніки тощо. Додатково слід зазначити наступні фактори, пов'язані з впливом воєнних витрат на економічне зростання: притік інвестиції у ОПК, закупівлі озброєнь і військової техніки, витрати на науково дослідницькі та науково дослідноконструкторські роботи (НДДКР) повертається додержавного бюджету у якості податків; державі як повному чи частковому власнику підприємств ОПК надходять значні обсяги дивідендів; кошти, витрачені на виплату грошового забезпечення особовому складу збройних сил стимулюють більш високі витрати на кінцеве споживання сімей військовослужбовців, що також стимулює економічне зростання.

Використання кореляційного аналізу часто має практичний результат, тому для співставлення результатів відповідне дослідження було проведено за трьома коефіцієнтами: коефіцієнт кореляції рангів Кендала та Спірмена, коефіцієнт знаків Фехнера.

У статистиці коефіцієнт кореляції рангу коефіцієнт (тау-коефіцієнт) Кендла. Він використовується у статистиці для вимірювання зв'язку між двома величинами. $t$-тест - це непараметричний тест статистичних гіпотез залежності на основі tкоефіцієнта. Зокрема, він $€$ мірою рангової кореляції, тобто подібності упорядкування даних, коли вони упорядкуванні за своєю величиною.

$$
\begin{gathered}
\tau=\frac{s}{\sqrt{\left[\frac{n(n-1)}{2}-U_{x}\right]\left[\frac{n(n-1)}{2}-U_{y}\right]}}, \text { де } \\
U_{x}=\frac{\sum t(t-1)}{2} \text { та } U_{y}=\frac{\sum t(t-1)}{2}, \text { де } \\
t-\text { число пов'язаних рангів в ряду } X \text { і } Y
\end{gathered}
$$
відповідно.

Коефіцієнт кореляції рангу Спірмена $\left(r_{s}\right)$ непараметрична міра статистичної залежності між двома змінними. Він оцінює наскільки добре можна описати відношення між двома змінними за допомогою монотонної функції. Якщо немає повторних значень даних, то коефіцієнт Спірмена дорівнює 1 або -1, це відбувається коли кожна змінна $€$ монотонною функцією від іншої змінної. Коефіцієнт кореляції, як і будьяке обчислення кореляції, підходить для безперервних та дискретних змінних, у тому числі порядкових. Кендала $(\tau)$, як правило, називають $t$ -

$$
\begin{gathered}
r_{s}=1-6 \cdot \frac{\sum_{j-1}^{n} \Delta_{j}^{2}+T_{A}+T_{B}}{n(n-1)}, \text { де } \\
T_{A}=\sum_{a}\left(a^{3}-a\right) \backslash 12 \text { та } T_{B}=\sum_{b}\left(b^{3}-b\right) \backslash 12, \text { де }
\end{gathered}
$$

$\Delta_{j}^{2}$ - сума квадратів різниць рангів, $a, b-$ об'єми кожної групи однакових рангів відповідно для результатів вимірювання двох змінних.

Коефіцієнт Фехнера $\left(k_{\mathrm{f}}\right)$ - це оцінка ступеня узгодженості напрямків відхилень індивідуальних значень факторного та результативного ознак від середніх значень факторного та результативного ознак. Коефіцієнт Фехнера поряд 3 такими коефіцієнтами, як коефіцієнт Спірмена і коефіцієнт Кендела, відноситься до коефіцієнтів кореляції знаків. Коефіцієнт кореляції знаків заснований на оцінці ступеня узгодженості напрямків відхилень індивідуальних значень факторного та результативного ознак від відповідних середніх.

$$
\begin{gathered}
k_{\mathrm{f}}=\frac{1}{\mathrm{n}} \sum_{\mathrm{i}=1}^{\mathrm{n}} \operatorname{sign}\left(\mathrm{x}_{\mathrm{i}}-\overline{\mathrm{x}}\right) \operatorname{sign}\left(\mathrm{y}_{\mathrm{i}}-\overline{\mathrm{y}}\right), \\
\text { при } \quad k_{\mathrm{f}}=\frac{C-H}{C+H^{\prime}},
\end{gathered}
$$

де $C$ - кількість збігів знаків відхилень спостережень випадкових величин від їх середніх значень; $H$ - кількість розбіжностей знаків відхилень спостережень випадкових величин від їх середніх значень.

Тобто, дослідження зв'язку між зміною обсягів витрат на потреби Міністерства Оборони та ВВП $\epsilon$ суто індивідуальною особливістю кожної держави. Країнами 3 
найбільшими значеннями таких коефіцієнтів, як: Кендела (застосовується для виявлення взаємозв'язку між кількісними або якісними показниками, якщо їх можна ранжувати), Спірмена (ранговий коефіцієнт кореляції, що більше придатний в порівняння зі звичайним коефіцієнтом для характеристики кореляцій у випадках нелінійного зв'язку і для даних, розподіл даних, розподіл яких відрізняється від нормального) та Фехнера (ґрунтується на застосуванні перших степенів знаків у відхиленнях від середньої у різних пар значень ознак) $€$ Китай, Німеччина, Росія, Румунія, Молдова, Польща, США та Україна. Країнами, у яких не підтверджено сильний зв'язок відповідної залежності $\epsilon$ : Чехія, Угорщина, Литва та Великобританія. Тобто у цих країнах вплив змін обсягів витрат на потреби оборони та зміною ВВП не має статистичної вагомості для подальшого аналізу (таблиця 1).

Таблиця 1 - Узагальнені результати визначення можливих зв'язків/залежностей між зміною обсягів витрат на потреби Міністерства Оборони та ВВП найближчих до України та провідних країн світу

\begin{tabular}{|c|c|c|c|c|c|}
\hline \multirow{2}{*}{$\begin{array}{l}\text { Країни } \\
\text { США }\end{array}$} & \multirow{2}{*}{$\begin{array}{c}\text { Коефіцієнт } \\
\text { Кендела } \\
\text { значний }\end{array}$} & \multicolumn{2}{|c|}{ Коефіцієнт Спірмена } & \multicolumn{2}{|c|}{$\begin{array}{c}\text { Коефіцієнт } \\
\text { Фехнера }\end{array}$} \\
\hline & & 0,74 & сильний та прямий & 0,62 & прямий \\
\hline Китай & значний & 1 & сильний та прямий & 1 & прямий \\
\hline Чехія & значний & 0,77 & сильний та прямий & \multicolumn{2}{|c|}{ зв'язок не значний } \\
\hline Угорщина & значний & 0,68 & помірний та прямий & \multicolumn{2}{|c|}{ зв'язок не значний } \\
\hline Литва & значний & 0,85 & сильний та прямий & \multicolumn{2}{|c|}{ зв'язок не значний } \\
\hline Польща & значний & 0,85 & сильний та прямий & 1 & прямий \\
\hline Румунія & значний & 0,97 & сильний та прямий & 0,71 & прямий \\
\hline Молдова & значний & 0,91 & сильний та прямий & 0,71 & прямий \\
\hline Росія & значний & 0,9 & сильний та прямий & 0,9 & прямий \\
\hline Україна & значний & 0,73 & сильний та прямий & 0,62 & прямий \\
\hline Німеччина & значний & 0,91 & сильний та прямий & 0,9 & прямий \\
\hline Великобританія & значний & 0,66 & помірний та прямий & 0,33 & прямий \\
\hline
\end{tabular}

Відповідно до проведеного кореляційного аналізу залежностей обсягів ВВП та оборонних витрат досліджуваних країн особливу увагу доцільно приділити економікам таким країнам як Великобританія, США та Угорщина. Саме у результатах аналізу цих країн присутній найнижчий ступінь кореляційного зв'язку, що $\epsilon$ свідченням більш коректного фінансування оборони з позиції “...за потребами...”, а не “...відсоток від ВВП...”. Тому, є доцільним проаналізувати їхні підходи до оборонного менеджменту як можливості удосконалення власного державного планування.

Головною метою воєнних витрат $\epsilon$ підвищення обороноздатності держави, в той час, як другорядним $€$ створення робочих місць та організація інноваційних промислових технологій (як варіант) тощо.
Існують суперечливі думки щодо взаємозалежності воєнних витрат і економічного зростання держави. Приклад України показує, що хоча воєнні витрати збільшилися, ВВП на душу населення впав, економічний розвиток сповільнився. Але ця залежність в більшій мірі виникла в наслідок наявного воєнного конфлікту, тому доцільно провести більш глибинний аналіз змін економічних процесів. Війна негативно впливає на вітчизняний економічний розвиток та на основні показники економічної діяльності в країні. Іншим негативним проявом $€$ чітка виражена необхідність зростання витрат на оборонні заходи та реформування Збройних Сил України, тобто, спостерігався значний приріст витрат на оборонну функцію держави в замін видатків на розвиток економіки, соціальної 
інфраструктури, зростання оплати праці та інші заходи економічного розвитку країни.

Так, непродуктивне використання національного доходу на воєнні цілі означає не тільки втрату національного багатства. Одночасно військові витрати створюють додатковий платоспроможний попит, що веде до збільшення грошової маси без

Таблиця 2 - Узагальнені результати визначення можливих зв'язків/залежностей між зміною обсягів витрат на потреби міністерства оборони та інфляційними процесами найближчих до України та провідних країн світу за допомогою коефіцієнтів Кендела, Фехнера та Спірмена

\begin{tabular}{|c|c|c|c|c|c|}
\hline Країни & Коефіцієнт Кендела & \multicolumn{2}{|c|}{ Коефіцієнт Спірмена } & \multicolumn{2}{|c|}{ Коефіцієнт Фехнера } \\
\hline США & незначний & \multicolumn{2}{|c|}{ зв'язок не значний } & \multicolumn{2}{|c|}{ зв'язок не значний } \\
\hline Китай & незначний & \multicolumn{2}{|c|}{ зв'язок не значний } & 0,55 & прямий \\
\hline Чехія & незначний & 0,44 & $\begin{array}{c}\text { слабкий та } \\
\text { прямий }\end{array}$ & \multicolumn{2}{|c|}{ зв'язок не значний } \\
\hline Угорщина & незначний & \multicolumn{2}{|c|}{ зв'язок не значний } & \multicolumn{2}{|c|}{ зв'язок не значний } \\
\hline Литва & значний & 0,517 & $\begin{array}{c}\text { помірний та } \\
\text { прямий }\end{array}$ & 0,52 & прямий \\
\hline Польща & незначний & \multicolumn{2}{|c|}{ зв'язок не значний } & \multicolumn{2}{|c|}{ зв'язок не значний } \\
\hline Румунія & значний & $-0,8$ & $\begin{array}{c}\text { сильний та } \\
\text { зворотній }\end{array}$ & $-0,52$ & зворотній \\
\hline Молдова & значний & $-0,592$ & $\begin{array}{c}\text { помірний та } \\
\text { зворотній }\end{array}$ & 0,48 & зворотній \\
\hline Росія & значний & $-0,754$ & $\begin{array}{c}\text { сильний та } \\
\text { зворотній }\end{array}$ & \multicolumn{2}{|c|}{ зв'язок не значний } \\
\hline Україна & незначний & \multicolumn{2}{|c|}{ зв'язок не значний } & \multicolumn{2}{|c|}{ зв'язок не значний } \\
\hline Німеччина & незначний & \multicolumn{2}{|c|}{ зв'язок не значний } & \multicolumn{2}{|c|}{ зв'язок не значний } \\
\hline $\begin{array}{l}\text { Велико- } \\
\text { британія }\end{array}$ & значний & 0,706 & $\begin{array}{c}\text { сильний та } \\
\text { прямий }\end{array}$ & 0,52 & прямий \\
\hline
\end{tabular}

Отже, диспропорційність, або незбалансованість державних витрат i доходів, що проявляється в дефіциті держбюджету. Якщо цей дефіцит фінансується за рахунок активного використання “друкарського верстата" лише призводить до збільшення маси грошей в обігу, а відповідно і до інфляції; інфляційне зростання цін може відбуватись, якщо фінансування інвестицій проводиться аналогічними методами. Особливо інфляційно небезпечними $\epsilon$ інвестиції, пов'язані з мілітаризацією економіки. Так, непродуктивне використання національного доходу на воєнні цілі означає не тільки втрату національного багатства. Одночасно воєнні витрати створюють додатковий відповідного товарного покриття, збільшення воєнних витрат $€$ однією з головних причин хронічних дефіцитів державного бюджету i збільшення державного боргу в багатьох країнах, для покриття якого держава збільшує грошову масу, що веде до підвищення інфляції (табл. 2). 
Румунія є єдиною країною (з досліджуваних), в котрій спостерігається стійкий зв'язок між змінами обсягів воєнних витрат та рівнів ВВП, інфляції, це $\epsilon$ наслідком “Європейської кризи біженців" 2015-2016 рр., а також «Урядової кризи» 2017 року (мал. 1).

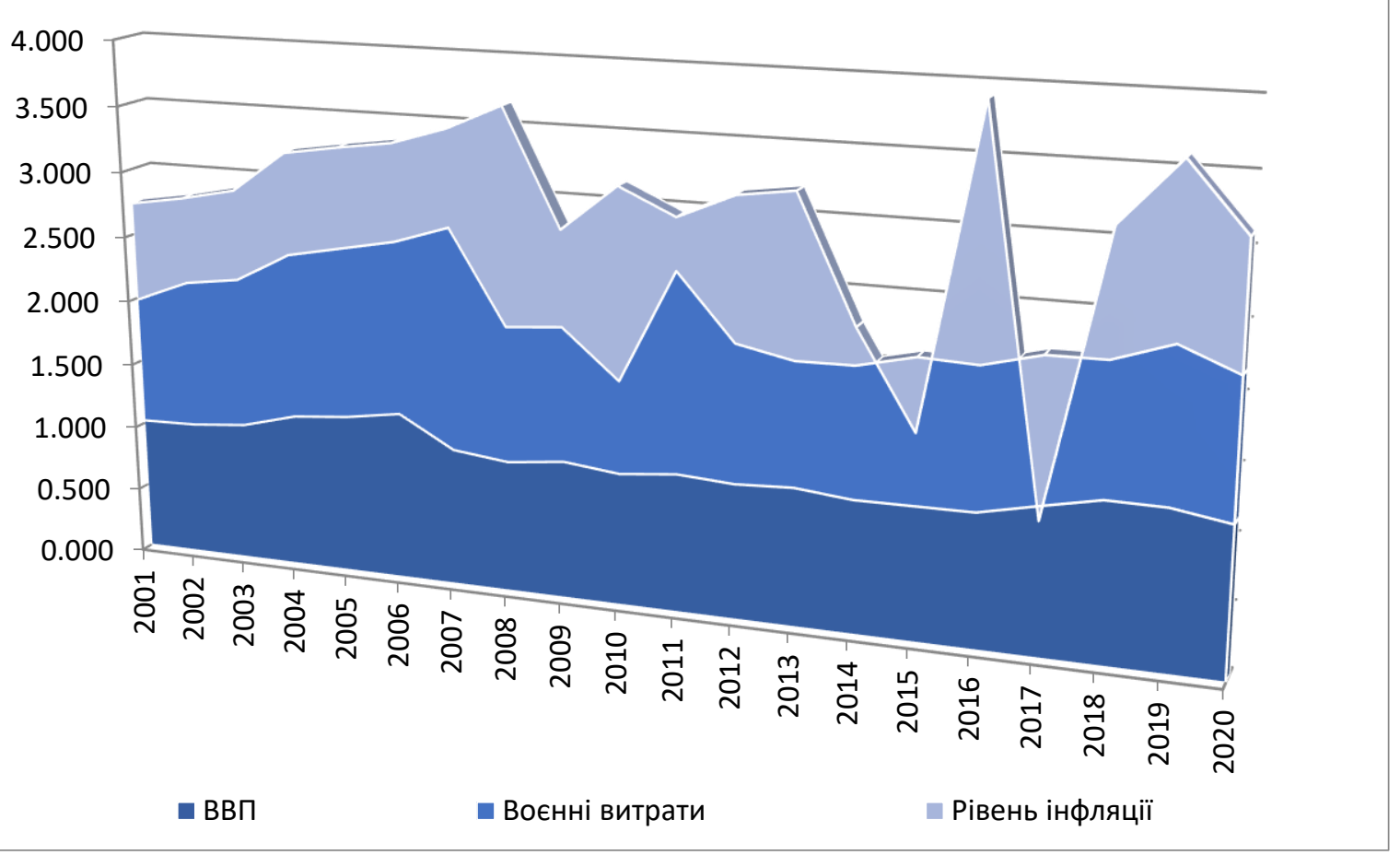

Малюнок 1 - Темпи змін обсягів ВВП, воєнних витрат та рівня інфляції Румунії

Тому $є$ цікавим дослідження економік цих двох країнах більш детальніше для можливого виявлення причинно-наслідкових зв'язків. Результати подібних досліджень можуть бути використані для визначення аналогій щодо поліпшення процесів власного державного довгострокового планування.

\section{Висновки}

Спроба математичного обґрунтування впливу воєнних витрат на економічний розвиток держави була здійснена багатьма як зарубіжними, так і вітчизняними вченими. Але, у жодному 3 проаналізованих досліджень не наведено математичної моделі, що була 6 призначена для визначення впливу воєнних витрат на зміну макроекономічних показників України. Таким чином, необхідно мати спеціальний методичний апарат, що дозволяє не тільки оцінювати вплив воєнних витрат на економічний розвиток, а й оптимізувати фінансування потреб 3 С таким чином, щоб їх задоволення приносило максимальний макроекономічний ефект. Основою для проведення таких досліджень $\epsilon$, по-перше, встановлення виду та сили зв'язку між досліджуваними елементами, по-друге, визначення аналогій на основі закордонного досвіду для можливого їх використання під час пошуку підходів щодо покращення економічного розвитку держави тощо.

В нашому випадку проводився аналіз між обсягами витрат на воєнні потреби та такими макроекономічними показниками як рівень інфляції та обсягами ВВП. Для відповідного аналізу були використані результати розрахунку таких коефіцієнтів кореляції, як: Кендела, Фехнера та Спірмена, що $\epsilon$ базовими, для визначення можливих зав' язків між (в нашому випадку) між зміною обсягів ВВП, інфляційних зрушень та обсягами фінансового ресурсу, що виділені на задоволення потреб оборонного сектору економіки.

Серед даних досліджуваних країн (в нашому випадку: США, Китай, Чехія, 
Угорщина, Литва, Польща, Румунія, Молдова, Росія, Україна, Німеччина та Великобританія) під час проведення досліджень у сфері "зв'язок воєнних витрат та ВВП держави", за результатами проведених розрахунків, доцільно звернути увагу на зміну ВВП США, Угорщини та Великобританії. В усіх показниках досліджуваних держав відсутній обернений зв'язок між зміною ВВП та воєнних витрат, що $€$ свідченням тісної взаємодії оборонних потреб відносно видаткової частини державного бюджету. Також, серед даних досліджуваних країн під час проведення досліджень у сфері “зв'язок воєнних витрат та інфляційних процесів держави", за результатами проведених розрахунків, доцільно звернути увагу на зміну інфляції Румунії та Молдови.

Перспективами майбутніх досліджень автори вважають, першочергово, у проведенні аналізу механізму впливу оборонних витрат на обсяги ВВП та рівень інфляції вищезазначених країн, так як отримані результати кореляційного аналізу свідчать щодо можливого використання їх досвіду у якості аналогій для підвищення власного економічного розвитку держави за рахунок більш раціонального управління воєнними витратами.

\section{Список використаних джерел}

1. Черняк О.І. Конвергенція витрат на оборонний комплекс та економічний розвиток країни [Текст] / О. І. Черняк, Г. О. Харламова // Вісник КНУТШ. - 2013. №.23. - С. 36-41.

2. Жуков Г. П. Военно-экономический анализ [Текст] / С.Ф.Викулов, Г. П.Жуков, В. Н. Ткачев, В. Я. Ушаков. - М. : Воениздат, 2001. -350 c.

3. Grasse Jr. Military expansion economic decline: the impact of military spending on u.s. economic performance [Text] / Jr. Grasse, W. Robert // New York: council on economic priorities/sharpe, 1983. - p. 218.

4. Military and economic security perspectives [Electronic resource]: URL: http://www.nbr.org/publications/element.a spx?id=156.

5. Pieroni L. Military Expenditure and Economic Growth [Text] / L. Pieroni. - Italy: Department of Economics, Finance and Statistics, University of Perugia (Part II), 2007. - p. 128-136.

6. Chapman G. Expenditures on defense affect a lot more than the deficit [Electronic resource] URL: http://www.context.org/iclib/ic20/ chapman

7. Dunne J. P. Models of Military Expenditure and Growth: A critical Review [Text] / J. P. Dunne, R. Smith and D. Willenbockel // Defence and Peace Economics, 2005. - p. 449-461.
8. Shieh J. The impact of military burden on longrun growth and welfare [Text] / J. Shieh, C. Lai, and W. Chang // Journal of Development Economics, 2002. - p. 443-454.

9. Ломакін В. К. Вплив військових витрат на економічний розвиток [Електронний pecypc]. - URL: http://epi.cc.ua/vliyanievoennyih-rashodov-ekonomicheskoe.html.

10. Вафин С. Бернанке: экономика США зависит от военных расходов. [Електронний ресурс]. - URL: http://www.vestifinance.ru/articles/61326.

11. Лавринов Г.А. О влиянии военных расходов на развитие экономики страны [Текст] / А. Г. Лавринов // Военная мысль. 2007. - № 12. - С. 19-24.

12. Малков С. Влияние военных расходов на экономику: сколько платить за военную безопасность? [Текст] / С. Ю. Малков, Д. С. Чернавский, Ю. В. Коссе, Н. И. Старков // Сценарий и перспектива развития России. - 2011. - № 1. - С. 288-304.

13. Данн Дж. Вопросы регулирования военных расходов в развивающихся странах [Текст] / Дж. П. Данн // Проблемы теории и практики управления. 1999. №3. - С. 40-58.

14. Пожаров А.И. Показатели и критерии военно-экономической безопасности [Текст] / А. И. Пожаров // Военная мисль. - 2000. - № 6. - С. 26.

15. Колінець Л. Б., Радинський С. В. Вплив 

зростання військових витрат на
економічний розвиток країн. Ефективна
економіка. 2020. № 8. - URL:
http://www.economy.nayka.com.ua/?op=1
$\& z=8095$ (дата звернення: 27.08.2021).
DOI: $10.32702 / 2307-2105-2020.8 .8$
16. Баронін А. Як військові конфлікти
впливають на економіку. URL: https://mind.ua/openmind/20173685-yak- vijskovi-konflikti-vplivayut-na-ekonomiku (дата звернення 4.08.2021 року).
17. Danek T. (2013). Analysis of Relationship between Military Expenditure and Economic Growth. The Business \& Management Review. Vol. 3(3). P.117-125.
18. Чеберяко О. Вплив макроекономічних показників на фінансування потреб оборони держави - К.: Вісник Київського національного університету імені Тараса Шевченка, №138. - 2012. - С. 45-49.
19. Проблеми та перспективи зміцнення стійкості фінансової системи України. Аналітична доповідь. К.: НІСД, 2020. - 71 с. 20. Sokhatskyi O. (2020) Military expenditures in situations of armed conflicts and their impact on the country is Economy. European Journal of Economics and Management. 2020. Volume 6. Issue 2. P. 16-27 DOI:10.46340/eujem.2020.6.211.
21. Оборонна реформа: системний підхід до оборонного менеджменту: монографія / А. Павліковський, В. Фролов, Ф. Саганюк та ін.; за заг. ред. д. військ. н. А. Сиротенка. - Київ: НУОУ. - 2020. - 274 с.
22. Чинники і тренди економічного зростання в Україні : колективна монографія / за ред. д-ра екон. наук М.І.Скрипниченко ; НАН України, ДУ «Ін-т екон. та прогнозув. НАН України». - Електрон. дані. - К., 2018. - 386 c.- URL: http://ief.org.ua/docs/mg/302.pdf

\title{
К вопросу повышения качества экономического развития страны путем учёта корреляционной связи между военными расходами и макроэкономическими показателями страны
}

\author{
Олег Семененко * 1 А; Игорь Москаленко 2 в; Марина Абрамова ${ }^{3}$ А;

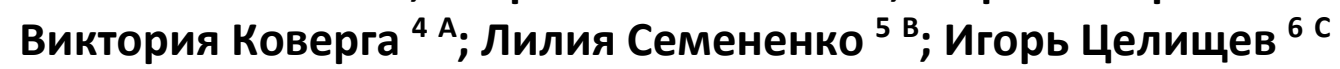 \\ Corresponding author: * ${ }^{1}$ д.в.н., с.н.с., начальник отдела, e-mail: aosemenenko@ukr.net, ORCID: 0000-0001-6477-3414 \\ 2 соискатель ученой степени, e-mail: aosemenenko@ukr.net \\ ${ }^{3}$ кандидат экономических наук, e-mail: aosemenenko@ukr.net, ORCID: 0000-0001-7644-9988 \\ ${ }^{4}$ соискатель ученой степени, e-mail: aosemenenko@ukr.net, ORCID: 0000-0002-9776-5522 \\ ${ }^{5}$ соискатель ученой степени, e-mail: selin-ua@ukr.net, ORCID: 0000-0002-5628-3586 \\ ${ }^{6}$ e-mail: aosemenenko@ukr.net, ORCID: 0000-0002-8027-4110
}

\footnotetext{
А Центральный научно-исследовательский институт Вооруженных Сил Украины, пр-кт Воздухофлотский 28 г. Киев, 03049, Украина

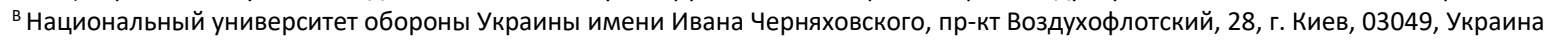
с Кафедра военной подготовки Национального авиационного университета, ул. Медовая 1, г. Киев, 03048, Украина
}

\section{Аннотация}

Проведенный авторами анализ имеющихся по данной тематике открытых публикаций дал возможность определить одним из возможных недостатков улучшения экономического развития государства на долгосрочную перспективу недостаточный учет последствий связей между изменением объемов военных расходов и макроэкономическими показателями.

По мнению авторов учета зарубежного опыта необходимо для полноценного анализа возможностей трансформации экономических процессов определения возможного влияния оборонных расходов на долгосрочное экономическое развитие собственного государства.

С помощью проведенного корреляционного анализа авторами получены обобщенные результаты определения возможных связей / зависимостей между изменениями объемов расходов на нужды Министерства Обороны (МО) и уровня валовых внутренних расходов (ВВП), инфляции, близких к Украине и ведущих стран мира. Это позволило выделить страны с положительным влиянием оборонных расходов на их экономические процессы. 
Дальнейшие исследования по данному направлению могут определить ряд аналогий, которые могут быть использованы для повышения экономического развития собственного государства.

Ключевые слова: военные расходы, экономическое развитие, макроэкономические показатели, корреляционный анализ, коэффициент Фехнера, коэффициент Спирмена, коэффициент Кендела.

\title{
On the issue of increasing the quality of economic development of the country by taking into account correlation between military expenditure and macroeconomic indicators of the country
}

\author{
Oleh Semenenko * 1 A; Ihor Moskalenko ${ }^{2}$ B; Maryna Abramova ${ }^{3}$ A; \\ Victoriia Koverga ${ }^{4}$ A; Liliia Semenenko ${ }^{5}$ B; Ihor Tselishchev 6 C \\ Corresponding author: * 1 Dr of military sciences, Senior Research Fellow, Head of Department, e-mail: aosemenenko@ukr.net, ORCID: 0000-0001-6477-3414 \\ ${ }^{2}$ Ph.D. student, Senior Researcher, e-mail: aosemenenko@ukr.net, ORCID: 0000-0002-7822-6419 \\ ${ }^{3}$ candidate of economic sciences, e-mail: aosemenenko@ukr.net, ORCID: 0000-0001-7644-9988 \\ ${ }^{4}$ Ph.D. student, e-mail: aosemenenko@ukr.net, ORCID: 0000-0002-9776-5522 \\ 5 Ph.D. student, e-mail: selin-ua@ukr.net, ORCID: 0000-0002-5628-3586 \\ ${ }^{6}$ e-mail: aosemenenko@ukr.net, ORCID: 0000-0002-8027-4110 \\ A Central Research Institute of Armaments and Military Equipment Armed Forces of Ukraine, 28, Povitroflotsky, ave, Kyiv, 03049, Ukraine

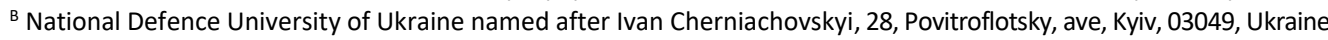 \\ ${ }^{\mathrm{C}}$ Department of Military Training of the National Aviation University, 1, Medova st., Kyiv, 03048, Ukraine
}

\begin{abstract}
The authors' analysis of available open publications made it possible to identify one of the possible shortcomings of improving the economic development of the state, not taking into account the consequences of changes in military spending and macroeconomic indicators of the state during medium and long-term government planning.

According to the authors, taking into account foreign experience is appropriate for a comprehensive analysis of the possibilities of transformation of their own economic processes. The correlation analysis generalized the results of determining possible links / dependencies between changes in the volume of expenditures for the needs of the Ministry of Defense and the level of gross domestic expenditure, inflation, closest to Ukraine and leading countries. This made it possible to single out countries with a possible positive impact of defense spending on their economic processes. Further research in this area may identify a number of analogies that should be used to improve the policy of economic development of their own country.
\end{abstract}

Keywords: military spending, economic development, macroeconomic indicators, correlation analysis, Fechner coefficient, Spearman coefficient, Kendel coefficient.

\section{References}

1. Chernyak O. I. Konverhentsiya vytrat na oboronnyy kompleks ta ekonomichnyy rozvytok krayiny. Visnyk KNUTSH. 2013. №. 23. P. 36-41.

2. Zhukov H. P. Voenno-ékonomycheskyy analyz Moscow. Voenyzdat. 2001. P. 350.

3. Grasse Jr. Military expansion economic decline: the impact of military spending on u.s. economic performance. New York: council on economic priorities/sharpe. 1983. p. 218.

4. Military and economic security perspectives. Available from: http://www.nbr.org/publications/element.a spx?id=156.

5. Pieroni L. Military Expenditure and Economic Growth. Italy: Department of Economics, 
Finance and Statistics, University of Perugia (Part II). 2007. p. 128-136.

6. Chapman G. Expenditures on defense affect a lot more than the deficit. Available from: http://www.context.org/iclib/ic20/chapman

7. Dunne J. P. Models of Military Expenditure and Growth: A critical Review. Defence and Peace Economics. 2005. P. 449-461.

8. Shieh J. The impact of military burden on longrun growth and welfare. Journal of Development Economics. 2002. p. 443-454.

9. Lomakin V. K. Vplyv viys'kovykh vytrat na ekonomichnyy rozvytok. Available from: http://epi.cc.ua/vliyanie-voennyihrashodov-ekonomicheskoe.html.

10. Vafyn S. Bernanke: ékonomyka SSHA zavysyt ot voennykh raskhodov. Available from: http://www.vestifinance.ru/articles/61326.

11. Lavrynov H. A. O vlyyanyy voennykh raskhodov na razvytye ékonomyky strany Voennaya mysl'. 2007. № 12. P. 19-24.

12. Malkov S. Vlyyanye voennykh raskhodov na ékonomyku: skol'ko platyt' za voennuyu bezopasnost'? Stsenaryy y perspektyva razvytyya Rossyy. 2011. № 1. P. 288-304.

13. Dann Dzh. Voprosy rehulyrovanyya voennykh raskhodov $v$ razvyvayushchykhsya stranakh. Problemy teoryy y praktyky upravlenyya. 1999. № 3. P. 40-58.

14. Pozharov A. Y. Pokazately y kryteryy voennoékonomycheskoy bezopasnosty. Voennaya mysl'. 2000. № 6. P. 26.

15. Kolinets' L. B., Radyns'kyy S. V. Vplyv zrostannya viys'kovykh vytrat na ekonomichnyy rozvytok krayin. Efektyvna ekonomika. 2020. № 8. Available from: http://www.economy.nayka.com.ua/?op=1

$\& z=8095$ DOI: 10.32702/2307-2105-2020.8.8

16. Baronin A. Yak viys'kovi konflikty vplyvayut' na ekonomiku. Available from: https://mind.ua/openmind/20173685-yakvijskovi-konflikti-vplivayut-na-ekonomiku

17. Danek T. Analysis of Relationship between Military Expenditure and Economic Growth. The Business \& Management Review. 2013. Vol. 3(3). P. 117-125.

18. Cheberyako O. Vplyv makroekonomichnykh pokaznykiv na finansuvannya potreb oborony derzhavy - K.: Visnyk Kyyivs'koho natsional'noho universytetu imeni Tarasa Shevchenka, 2012. №138. P. 45-49.

19. Problemy ta perspektyvy zmitsnennya stiykosti finansovoyi systemy Ukrayiny. Analitychna dopovid'. Kyiv: NISD. 2020. P. 71. 20. Sokhatskyi O. Military expenditures in situations of armed conflicts and their impact on the country is Economy. European Journal of Economics and Management. 2020. Volume 6. Issue 2. P. 16-27 DOI:10.46340/eujem.2020.6.211.

21. Pavlikovs'kyy A., Frolov V. Oboronna reforma: systemnyy pidkhid do oboronnoho menedzhmentu: monohrafiya yyiv: NUOU. 2020. P 274.

22. Chynnyky i trendy ekonomichnoho zrostannya $v$ Ukrayini : kolektyvna monohrafiya / za red. d-ra ekon. nauk M. I. Skrypnychenko. NAN Ukrayiny. DU «In-t ekon. ta prohnozuv. NAN Ukrayiny». 2018. P. $386 . \quad$ Available from: http://ief.org.ua/docs/mg/302.pdf. 